\title{
PEMBELAJARAN IPA BERBASIS ANALOGI MENGGUNAKAN METODE FAR (FOKUS AKSI REFLEKSI) UNTUK MENINGKATKAN PEMAHAMAN KONSEP MAHASISWA PGSD
}

\section{Siti Fatimah}

Universitas Sebelas Maret

\section{Sejarah Artikel}

Diterima 1 September 2017

Disetujui 1 Oktober 2017

Diterbitkan 1 Desember 2017

\section{Kata Kunci}

Pembelajaran IPA, Analogi, metode FAR, Pemahaman Konsep

\begin{abstract}
Abstrak
Telah dilakukan penelitian yang bertujuan untuk mengetahui peningkatan pemahaman konsep mahasiswa pada pembelajaran IPA berbasis analogi menggunakan metode FAR. Populasi dalam penelitian ini adalah seluruh mahasiswa semester 1 TA 2016/2017 berjumah dua kelas. Teknik pengambilan sampel adalah teknik sampel jenuh yaitu seluruh populasi dijadikan sebagai sampel. Penelitian ini merupakan penelitian kuasi eksperimen. Instrumen yang digunakan adalah lembar tes, lembar observasi, dan lembar interview. Uji hipotesis menggunakan uji Mann-Withney $U$. Hasil penelitian menunjukkan bahwa: 1) ada pengaruh pembelajaran IPA berbasis analogi menggunakan metode FAR terhadap pemahaman konsep teori pembentukkan tata surya; 2) ada peningkatan pemahaman konsep mahasiswa PGSD pada materi teori pembentukkan tata surya melalui analogi menggunakan metode FAR..
\end{abstract}

\section{Cara Mengutip}

Fatimah, Siti. (2017). Pembelajaran IPA Berbasis Analogi Menggunakan Metode FAR (Fokus Aksi Refleksi) untuk Meningkatkan Pemahaman Konsep Mahasiswa PGSD. DWIJACENDEKIA Jurnal Riset Pedagogik, 1(2), 89-95. 


\section{PENDAHULUAN}

Tantangan bagi pendidik dalam mengajarkan materi sains adalah materi-materi yang bersifat abstrak. Pendidik harus memahami dan memilih teknik/cara yang tepat dalam memahamkan peserta didik tentang materi sains yang bersifat abstrak. Salah satu materi IPA yang bersifat abstrak adalah teori terbentuknya sistem tata surya. Meskipun materi tata surya merupakan salah satu materi IPA yang berkaitan dengan kehidupan sehari-hari seperti matahari, bulan, dan bumi. Namun, diperlukan teknik yang tepat agar pembelajaran tidak hanya bersifat teoritis dan ceramah.

Berdasarkan hasil observasi, selama ini pembelajaran sains pada materi teori pembentukkan sistem tata surya masih sebatas menggunakan metode diskusi dan presentasi. Kelebihan dari metode tersebut adalah mampu melatih mahasiswa dalam berkomunikasi sedangkan kekurangannya yaitu mahasiswa belum maksimal dalam memahami materi karena hanya menggunakan media powerpoint (ppt), sedangkan teknik presentasi masih menggunakan ceramah. Oleh karena itu, hal ini berdampak pada kesulitan mahasiswa dalam memahami materi secara menyeluruh.

\section{Muhammad Rifansyah} menjelaskan bahwa materi tata surya bersifat abstrak dan banyak hafalan serta sulit untuk dibayangkan sehingga membuat peserta didik kesulitan dalam memahami pembelajaran. Hakikatnya, pembelajaran sains harus menekankan pada empat hal, yaitu mencakup produk, proses, sikap, dan aplikasi. Keempat hal tersebut harus menjadi dasar utama dalam mengajarkan sains dan mengembangkan kemampuan mahasiswa yang berbasis saintis. Salah satu cara yang dapat digunakan dalam mengajarkan materi teori pembentukkan sistem tata surya yang bersifat abstrak adalah menggunakan analogi.

Kanzun Fikri (2012) menjelaskan bahwa salah satu upaya untuk memahamkan konsep-konsep abstrak pada materi fisika, pendidik dapat menggunakan analogi dalam menjelaskan konsep-konsep abstrak yang sulit untuk memudahkan peserta didik dalam memahami konsep tersebut.

Penggunaan analogi sangat membantu khususnya jika materi ajar berhubungan dengan wilayah di luar jangakauan panca indera manusia atau alat bantu visual untuk pengamatan. Ade San Putra (2016) menyebutkan bahwa dengan menggunakan analogi dapat menghubungkan konsep sains yang asing dan abstrak dengan analoganalog yang nyata yang dapat membantu siswa memahami objek dan proses sains. Sedangkan Boo Hong Kwen \& Toh Kok Aun dalam Apit Fathurrohman (2014) menjelaskan beberapa kelebihan mengajar menggunakan analogi yaitu analogi sebagai alat untuk mengajarkan perubahan konseptual, menyediakan visualisasi dan pemahaman pada konsep yang abstrak yang merujuk pada contohcontoh dalam kehidupan nyata, memicu minat belajar siswa karena memiliki efek motivasi, dan menuntut 
guru untuk mempertimbangkan prakonsepsi siswa terhadap materi yang akan diajarkan serta dapat mengurangi miskonsepsi pada materi yang diajarkan. Baiq Asma Nufida (2013) menjelaskan bahwa penggunaan analogi dapat membantu siswa dalam memvisualiasasikan materi.

Apabila penggunaan analogi dilakukan secara tepat maka akan sangat membantu siswa dalam memahami konsep, namun bila tanpa perencanaan maka akan menimbulkan miskonsepsi. Miskonsepsi dapat terjadi apabila siswa tidak menyadari tentang keterbatasan analogi yang digunakan. Oleh karena itu pembelajaran analogi perlu dipandu/diarahkan dengan memperhatikan aspek FAR (Fokus Aksi Refleksi).

Peter Aubusson (2009) menjelaskan bahwa metode FAR telah terbukti dapat meningkatkan pemahaman konsep sains dan mengurangi konstruksi konsep-konsep alternatif. Harrison \& Coll dalam Jesper Haglund (2013) menyebutkan bahwa penggunaan tahapan FAR pada pembelajaran analogi telah populer dan dapat diandalkan bagi pendidik baik pada materi kimia, biologi, fisika, serta tentang bumi dan antariksa di tingkat sekolah dasar atau menengah. Ade San Putra (2016) menjelaskan bahwa metode FAR dapat membantu guru memaksimalkan manfaat dan meminimalkan permasalahan dalam menggunakan analogi saat pembelajaran sains. Metode FAR memberikan strategi pedagogik sederhana dalam mengefektifkan pembelajaran dengan analogi, yang bertujuan untuk mengajarkan konsep target yang komples dan abstrak.

Metode FAR terdiri dari tiga tahap yaitu Fokus (focus), Aksi (action), dan Refleksi (reflection). Tahap fokus, dirancang untuk mengarahkan pada perencanaan sebelum pembelajaran dengan memfokuskan pada masalah konsep yang kompleks dan memeriksa pengetahuan awal siswa. Tahap aksi, guru hendaknya memperhatikan tingkat keakraban siswa dengan analog. Siswa dalam tahap ini akan memetakan kemiripan dan ketidakmiripan ciri-ciri analog dengan konsep target. Tahap refleksi, guru dan siswa akan mendiskusikan kembali kejelasan dan kegunaan dari analog yang telah digunakan untuk memahami konsep target.

Telah banyak penelitian yang telah dilakukan dalam pembelajaran sains menggunakan analogi. Ade San Putra (2016) mendapatkan temuan bahwa pembelajaran kimia berbasis analogi menggunakan metode FAR efektif untuk meningkatkan penguasaan konsep siswa. Baiq Asma Nufida (2013) menghasilkan temuan bahwa model jembatan analogi dalam pembelajaran kimia berpengaruh secara signifikan terhadap pemahaman aspek mikroskopik siswa sehingga dapat disimpulkan bahwa pembelajaran kimia menggunakan model jembatan analogi dapat digunakan untuk membantu siswa dalam memahami kajian aspek mikroskopik. Selanjutnya penelitian yang dilakukan oleh Kanzun Fikri (2012) menghasilkan simpulan bahwa pembelajaran fisika dengan analogi mampu meningkatkan hasil belajar kognitif siswa. 


\section{METODE PENELITIAN}

Jenis penelitian ini adalah Quasi experiment menggunakan The nonequivalent Pretest-Posttest Design.

Tabel 1. The non-equivalent pretestposttest design

\begin{tabular}{cccc}
\hline Kela & $\begin{array}{c}\text { Pretes } \\
\text { S }\end{array}$ & $\begin{array}{c}\text { Perlakua } \\
\mathbf{n}\end{array}$ & $\begin{array}{c}\text { Posttes } \\
\boldsymbol{t}\end{array}$ \\
\hline IA & $\mathrm{O}_{1}$ & $\mathrm{X}_{1}$ & $\mathrm{O}_{2}$ \\
IB & $\mathrm{O}_{1}$ & $\mathrm{X}_{2}$ & $\mathrm{O}_{2}$ \\
\hline
\end{tabular}

Tabel 1 menunjukkan bahwa kelas IA diberikan perlakuan pembelajaran IPA berbasis analogi menggunakan metode FAR dan kelas IB diberikan perlakuan pembelajaran IPA berbasis analogi. Masing-masing kelas diberikan pre-test dan post-test.

Populasi dalam penelitian ini adalah seluruh mahasiswa PGSD semester I TA 2016/2017 sebanyak 2 kelas. Teknik sampel yang digunakan adalah teknik sampel jenuh yaitu menggunakan seluruh populasi sebagai sampel dengan ketentuan bahwa kelas IA menggunakan pembelajaran berbasis analogi melalui metode FAR, dan kelas IB menggunakan pembelajaran berbasis analogi. Instrumen yang digunakan dalam penelitian ini berbentuk lembar tes, lembar observasi, dan lembar wawancara.

Uji hipotesis menggunakan uji Mann Withney $U$ test dengan ketentuan jika $p$-value $<0,05$ maka hipotesis nol ditolak. Untuk mengetahui besar peningkatan keterampilan proses sains maka diuji dengan menggunakan persamaan $\mathrm{N}$ Gain, yaitu

$$
N \text {-Gain }=\frac{\text { skor post test }- \text { skor pre test }}{\text { skor maksimum-skor pre test }}
$$

(Pers. 1)

Tabel 2. Klasifikasi $\mathbf{N}$-Gain

\begin{tabular}{cc}
\hline Rerata $N$-Gain & Kualifikasi \\
\hline $0,70<N$-Gain $\leq$ & Tinggi \\
1,00 & \\
$0,30<N$-Gain $\leq$ & Sedang \\
0,70 & \\
$N$-Gain $\leq 30$ & Rendah \\
\hline
\end{tabular}

\section{PEMBAHASAN}

Pembelajaran sains berbasis analogi untuk mengukur pemahaman konsep pada materi teori pembentukkan sistem tata surya dilakukan dengan memberika pre-test berupa pertanyaan-pertanyaan tentang pemahaman mahasiswa tentang teori pembentukkan tata surya sebelum diberikan perlakuan kemudian dilanjutkan dengan memberikan posttes pada akhir pembelajaran setelah diberikan perlakuan.

Tabel 3. Deskripsi nilai rata-rata pre tes dan post test

\begin{tabular}{lcc}
\hline Kelas & $\begin{array}{c}\text { Nilai Pre } \\
\text { Test }\end{array}$ & $\begin{array}{c}\text { Nilai Post } \\
\text { Test }\end{array}$ \\
\hline Eksperimen & 40 & 89,2 \\
Kontrol & 36 & 80,7 \\
\hline
\end{tabular}

Berdasarkan tabel 3 dapat dijelaskan bahwa kelas eksperimen memiliki nilai rata-rata pre test dan post test yang lebih tinggi daripada kelas kontrol. Selanjutnya untuk mengetahui pengaruh dari metode yang digunakan adalah menggunakan uji statistik nonparametrik yaitu menggunakan uji Mann withney $U$. 
Tabel 4. Ringkasan hasil uji Mann Withney $U$

Test Statistics ${ }^{a}$

\begin{tabular}{lr}
\hline & postanalogi \\
\hline Mann-Whitney U & 307.500 \\
Wilcoxon W & 1127.500 \\
Z & -4.769 \\
Asymp. Sig. (2-tailed) & .000 \\
\hline
\end{tabular}

a. Grouping Variable: kelas

Berdasarkan tabel 4 dapat diketahui bahwa nilai signifikasi hasil uji Mann Withney $U$ adalah kurang dari 0,05. Artinya ada pengaruh pembelajaran berbasis analogi terhadap pemahaman konsep mahasiswa pada materi teori pembentukkan tata surya. Pembelajaran berbasis analogi menggunakan metode FAR terbukti berpengaruh secara signifikan terhadap pemahaman konsep mahasiswa daripada pembelajaran yang hanya menggunakan analogi. Selain memiliki pengaruh terhadap pemahaman konsep, terdapat peningkatan pemahaman konsep mahasiswa pada materi teori pembentukkan tata surya.

Tabel 5. Deskripsi Nilai Rerata N-Gain

\begin{tabular}{lcc}
\hline \multicolumn{1}{c}{ Kelas } & $\begin{array}{c}\text { Nilai } \\
\text { Rerata N- } \\
\text { Gain }\end{array}$ & Kualifikasi \\
\hline Eksperimen & 0,82 & Tinggi \\
Kontrol & 0,69 & Rendah \\
\hline
\end{tabular}

Berdasarkan tabel 5 terdapat peningkatan di masing-masing kelas. Berdasarkan nilai rerata N-Gain, besar peningkatan di kelas eksperimen lebih tinggi daripada peningkatan di kelas kontrol. Artinya pembelajaran berbasis analogi menggunakan metode FAR lebih baik dalam meningkatkan pemahaman konsep mahasiswa
PGSD pada materi teori pembentukkan tata surya.

Pembelajaran berbasis analogi menggunakan metode FAR pada tahap fokus (focus) dilakukan dengan menggunakan tenknik brainstorming dengan mengajukan pertanyaan seperti "bagaimana alam semesta yang tidak terbatas ini terbentuk?". Jawaban-jawaban dari mahasiswa menjadi pengetahuan awal yang akan dijadikan panduan bagi dosen dalam mengarahkan ke konsep selanjutnya. Berdasarkan jawaban-jawaban dari mahasiswa, pemahaman mahasiswa tentang teori pembentukkan tata surya masih sangat kurang. Mahasiswa cenderung hanya mengingat nama (seperti: teori big bang, teori nebula, dan teri bintang kembar). Ade San Putra (2016) menjelaskan bahwa metode FAR pada fase fokus merupakan jembatan penghubung dalam memahamkan pengetahuan baru yang abstrak yaitu dengan menggali pengetahuan-pengetahuan awal siswa. Hal tersebut dapat memberikan stimulus-stimulus bagi siswa untuk belajar dan mampu manarik perhatian siswa dalam mempelajari materi selanjutnya.

Pada tahap aksi (action), pendidik memberikan contoh analogi berdasarkan pengetahuan awal yang didapatkan dari mahasiswa. Selama ini yang dipahami oleh mahasiswa tentang teori big bag adalah bahwasanya tata surya terbentuk karena adanya ledakan yang sangat besar. Jawaban tersebut digunakan oleh pendidik untuk mengklarifikasi konsep dengan menggunakan analogi.

Salah satu analogi yang digunakan dalam menjelaskan teori big bang adalah saat pembuatan kue (cake). 
Mula-mula bentuk kue sebelum dipanggang adalah memampat. Jika kue yang telah diberikan hiasan coklat kecil-kecil dipanggang, maka lama kelamaan kue tersebut akan mengembang dengan jarak coklat kecil-kecil di atasnya akan berjauhan posisinya. Dapat juga dikembangkan analogi yang lain seperti sebuah balon. Jika balon diberi tanda titiktitik/lingkaran kecil, maka ketika ditiup akan mengembang dan jarak lingkaran kecil/titik-titik akan saling menjauh. Analogi tersebut menjelaskan teori big bang bahwa pembentukkan tata surya dikarenakan adanya proses ekspansi yang terus terjadi. Analogi ini sebagai contoh untuk teori pembentukkan tata surya lain yang akan dikembangkan oleh mahasiswa dengan cara berkelompok. Mahasiswa diarahkan untuk diskusi dan membuat contoh analogi yang kemudian dipresentasikan. Sebagian mahasiswa membuat analogi menggunakan model role play (bermain peran).

Berdasarkan hasil observasi, analogi yang dikembangkan oleh mahasiswa menggunakan bermain peran mampu membuat kelas lebih menyenangkan. Hal ini dikarenakan ketika menggunakan bermain peran, mahasiswa seolah-olah berada pada situasi yang sebenarnya. Sehingga hal itu berdampak pada pemahaman mahasiswa terhadap konsep yang dijelaskan melalui bermain peran. Selain itu, bermain peran mampu menggambarkan kondisi yang hampir sesuai dengan kenyataan. Sebagai contoh, analogi tentang teori planetesimal menggunakan bermain peran adalah ada mahasiswa yang bertugas sebagai matahari sebanyak 3 dan 1 yang bertugas sebagai bintang lain dengan ukuran lebih besar yang akan melewati matahari tersebut. Ketika bintang yang besar melintas sangat cepat dan berada sangat dekat dengan matahari, sebagian materi matahari akan terlepas dan bertebaran di lintasan orbit. Dua mahasiswa yang bertugas sebagai matahari melepaskan diri dan berubah menjadi materi yang terlepas dari matahari yang akan dijadikan sebagai pusat tata surya. Dua mahasiswa yang terlepas beredar dengan orbit mengitari matahari dan berubah menjadi planet-planet. Melalui bermain peran ini, mahasiswa terlihat antusias menyimak proses adegan demi adegan dengan disertai narasi yang dibacakan.

Analogi dengan bermain peran ini sejalan dengan penelitian Shilvya Nanulaitta (2012) menjelaskan bahwa pembelajaran menggunakan bermain peran efektif digunakan dalam menjelaskan konsep tata surya. Setelah siswa mengikuti proses pembelajaran dengan bermain peran dapat membantu siswa menguasai indikator pembelajaran materi tata surya. Selain efektif untuk menjelaskan materi tata surya, bermain peran dapat memberikan kesempatan kepada siswa untuk mengembangkan keterampilan, memperlancar interaksi antara pendidik dan siswa sehingga proses pembelajaran lebih efektif.

Siti Hadija (2014) menyebutkan bermain peran sangat menarik bagi siswa, sehingga memungkinkan kelas menjadi dinamis dan penuh antusias serta berkesan dengan kuat dan tahan lama dalam ingatan siswa. Peter Aubusson dan Stephen Fogwill (2006) menghasilkan temuan penggunaan analogi dengan bermain peran membantu siswa dalam 
memahami materi serta menjadikan siswa antusias dalam pembelajaran kimia. Bermain peran menyediakan model fisik dan konkret untuk mewakili gagasan yang berbeda. Selain membangun permainan peran, siswa juga dapat mengembangkan pemahaman materi lebih baik.

Selanjutnya Hamzah B. Uno (2007: 25) menjelaskan bahwa role play (bermain peran) merupakan model yang diciptakan berdasarkan asumsi bahwa sangatlah mungkin menciptakan analogi otentik ke dalam suatu situasi permasalahan kehidupan nyata. Berdasarkan penjelasan tersebut dapat disimpulkan bahwa pembelajaran berbasis analogi dapat menggunakan model bermain peran untuk menjelaskan materi teori pembentukkan tata surya.

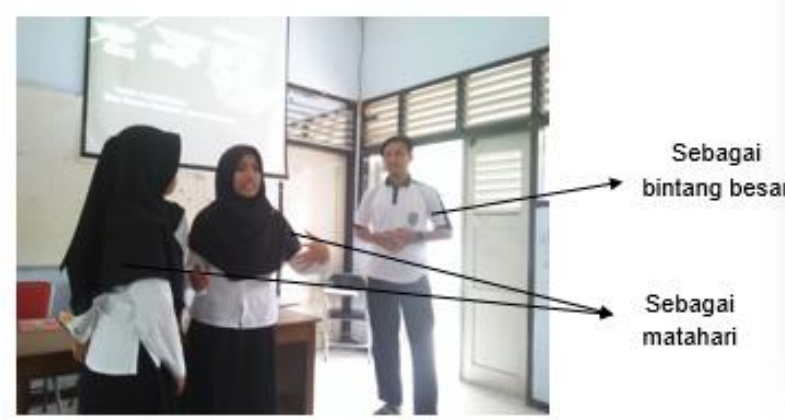

\section{Gambar 1. Analogi Teori Planetesimal melalui bermain peran}

Model analogi yang digunakan oleh mahasiswa selanjutnya adalah menggunakan media benda konkret seperti gelembung-gelembung sabun untuk menjelaskan teori creatio continua. Teori ini menjelaskan bahwa alam semesta tidak berawal dan tidak berakhir. Seperti gelembunggelembung sabun yang ditiup, ketika gelembung sabun ditiup lama kelamaan akan menghilang akibat pemuaian namun akan terbentuk gelembung sabun yang lain, begitu seterusnya. Menganalogikan materi dengan benda konkret telah banyak dikaji oleh beberapa penelitian. Seperti penelitian yang dilakukan oleh Apit Fathurohman (2014) menggunakan analogi sistem air untuk menjelaskan rangkaian listrik.

Penelitian yang dilakukan oleh Peter Aubusson (2009) yang menganalogikan alat optik kamera seperti alat indera mata serta pembiasaan dianalogikan seperti pergerakan roda. Penelitian Baiq Asma Nufida (2013) menganalogikan semut untuk menjelaskan proses pelarutan, analogi bus untuk menjelaskan tipe larutan, kelarutan, dan reaksi pengendapan.
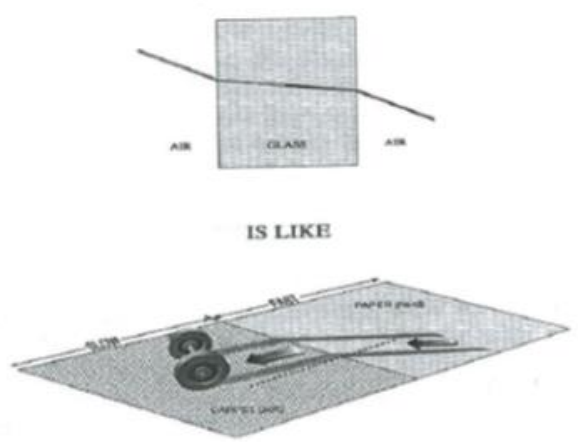

\section{Gambar 2. Analogi pembiasan pada roda}

(Sumber: Peter Aubusson, 2009)

Selanjutnya pada tahap refleksi (reflection), pendidik dan mahasiswa mengevaluasi penggunaan analogi yang digunakan. Berdasarkan hasil observasi selama pembelajaran, mahasiswa cukup memahami analogi yang telah digunakan oleh kelompok yang lain meskipun ada beberapa analogi yang masih perlu perbaikan.

Evaluasi dalam penggunaan analogi dalam pembelajaran sangat penting. Hal ini dikarenakan, pemilihan analogi 
yang digunakan oleh pendidik harus tepat dan dapat memberikan pemahaman kepada mahasiswa. Apabila analogi yang digunakan dapat memahamkan kosep yang disampaikan, maka analogi tersebut dapat digunakan sebagai analogi yang tepat pada materi tersebut. Ade San Putra (2016) menjelaskan bahwa tahap refleksi membantu siswa dalam merefleksi kembali analogi yang digunakan. Kejelasan dan manfaat analogi yang digunakan akan menjadikan siswa dan pendidik dapat sama-sama memperbaiki analogi yang digunakan.

\section{SIMPULAN}

Hasil penelitian menunjukkan bahwa: 1) ada pengaruh pembelajaran IPA berbasis analogi menggunakan metode FAR terhadap pemahaman konsep teori pembentukkan tata surya; 2) ada peningkatan pemahaman konsep mahasiswa PGSD pada materi teori pembentukkan tata surya melalui analogi menggunakan metode FAR.
Pembelajaran berbasis analogi membutuhkan kreativitas dalam menciptakan dan mengembangkan sebuah analogi agar tidak menimbulkan miskonsepsi. Untuk menciptakan pembelajaran analogi yang baik dan tepat selain menggunakan metode FAR dapat menggunakan model jembatan analogi.

\section{DAFTAR PUSTAKA}

Ade San Putra, dkk. 2016. Implementasi Pembelajaran Kimia Berbasis Analogi Menggunakan Metode FAR pada Materi Struktur Atom untuk Mneingkatkan Penguasaan Konsep Siswa. Prosising Seminar Nasional Kimia dan Pembelajarannya UNESA, 98103.

Apit Fathurohman. 2014. Analogi dalam Pengajaran Fisika. Jurnal Inovasi dan Pembelajaran Fisika, Vol.1 (1): 74-77.

Baiq Asma Nufida. 2013. Model Jembatan Analogi dalam Pembelajaran Kimia untuk Membantu Pemahaman Aspek Mikroskopik Siswa. Jurnal Kependidikan, Vol 12 (2): 115120.

Hamzah B. Uno. 2007. Model Pembelajaran. Jakarta: PT. Bumi Aksara.

Jesper Haglund. 2013. Collaborative and Self-Generated Analogies in Science Education. Journal Studies in Science Education, Vol. 49 (1): 35-68.

Kanzun Fikri, dkk. 2012. Penerapan Pembelajaran Fisika dengan Analogi untuk Meningkatkan Hasil Belajar Siswa SMA. Unnes Physics Education Journal, Vol. 1 (2): 1-4.

Muhammad Rifansyah, dkk. 2017. Pengembangan Perangkat Pembelajaran IPA pada Pokok Bahasan Tata Surya. Jurnal 
Berkala Ilmiah Pendidikan Fisika, Vol 5 (3): 286-296.

Peter Aubusson \& Stephen Fogwill. 2006. Role Play as Analogical Modelling in Science. Science and Technology Education Library, Springer. HIm: 93-104.

Peter Aubusson, dkk. 2009. Learning and Teaching Science With Analogies and Metaphors. The World of Science Education. Handbook of Research in Australian, 199-216. Sense Publishers.
Shilvya Nanulaitta. 2012. Efektivitas Penggunaan Model Pembelajaran Bermain Peran (Role Playing) Materi Tata Surya dalam Mencapai Hasil Belajar pada Siswa Kelas IX SMP Negeri 11 Ambon. Jurnal Manajemen Pendidikan, Vol 1 (1): 21-30.

Siti Hadija. 2014. Penerapan Model Pembelajaran Bermain Peran untuk Meningkatkan hasil Belajar IPA Siswa Kelas III SDN Randomayang. Jurnal Kreatif Tadulako Online, Vol 3 (2): 105112. 